\title{
Money Growth and the Size of the Federal Debt
}

\author{
Keith M. Carlson
}

$\mathbf{F}$

EDERAL debt held by the public (including the Federal Reserve System/ has risen relative to GNP over the past 10 years, with most of the increase occurring since 1981 (see chart 1). This recent increase in the federal debt-GNP ratio reverses a downward trend that had prevailed from the end of World War II. Furthermore, as of early this year, the Congressional Budget Office (CBO) projected that a continuation of current budget policies would lead to further rises in the debt-to-GNP ratio through 1989.

This change in trend is viewed with concern by most economic analysts. According to the $\mathrm{CBO}$ :

Historical experience suggests that increases and decreases in federal debt relative to GNP have been accompanied by approximately offsetting changes in non-federal debt as a percentage of GNP. Similarly. growth trends in the federal debt-GNP ratio appear to have been mirrored by opposite trends in the capitaloutput ratio."

Should history repeat itself, the rising federal debtGNP ratio will produce slower economic growth and a lower standard of living than would otherwise occur.

The accuracy of the CBO's projections depends, of course, on how accurately it is able to predict both deficits and future GNP? Two problems make it dif-

Keith $M$. Carlson is a research officer at the Federal Reserve Bank of St. Louis. Thomas A. Pollmann provided research assistance.

${ }^{1} \mathrm{CBO}$ (February 1984), part I, p. 75.

aFor a critique of the procedures used by the CBO and the Office of Management and Budget, see Klein (1984). ficult to obtain accurate projections of these two variables. First, these variables are interrelated; consequently, their feedback effects must be taken into account. Second, assumptions about the future course of monetary policy are crucial to the analysis; different assumptions will produce widely varying projections of both future deficits and future GNP.

The purpose of this article is to examine the importance of monetary policy assumptions in the assessment of the fedenal debt-GNP ratio. To aid in this examination, simulations from a modified version of a $S t$. Louis-type model are used in conjunction with a model of budget and debt determination. Because this model is sensitive to changes in money growth, it can be used to determine the effect of alternative monetary policies on the federal debt-GNP ratio.

\section{A FRAMEWORK FOR ANALYSIS}

The role for monetary policy in the determination of strategic budget variables can be described with the aid of a schematic diagram (see page 61. For a given tax structure and set of outlay programs, the economic variables - real GNP, unemployment, the price level and interest rates - impinge strongly to determine the budget outcome in a given period:" These variables, in tum, are affected by the growth of the money stock. The size of the federal debt held by the public

In this diagram, the connection between economic variables and budget variables is predominantly in one direction, reflecting primarily the results of previous econometric studies. 


\section{A Schematic Diagram of Budget Determination}

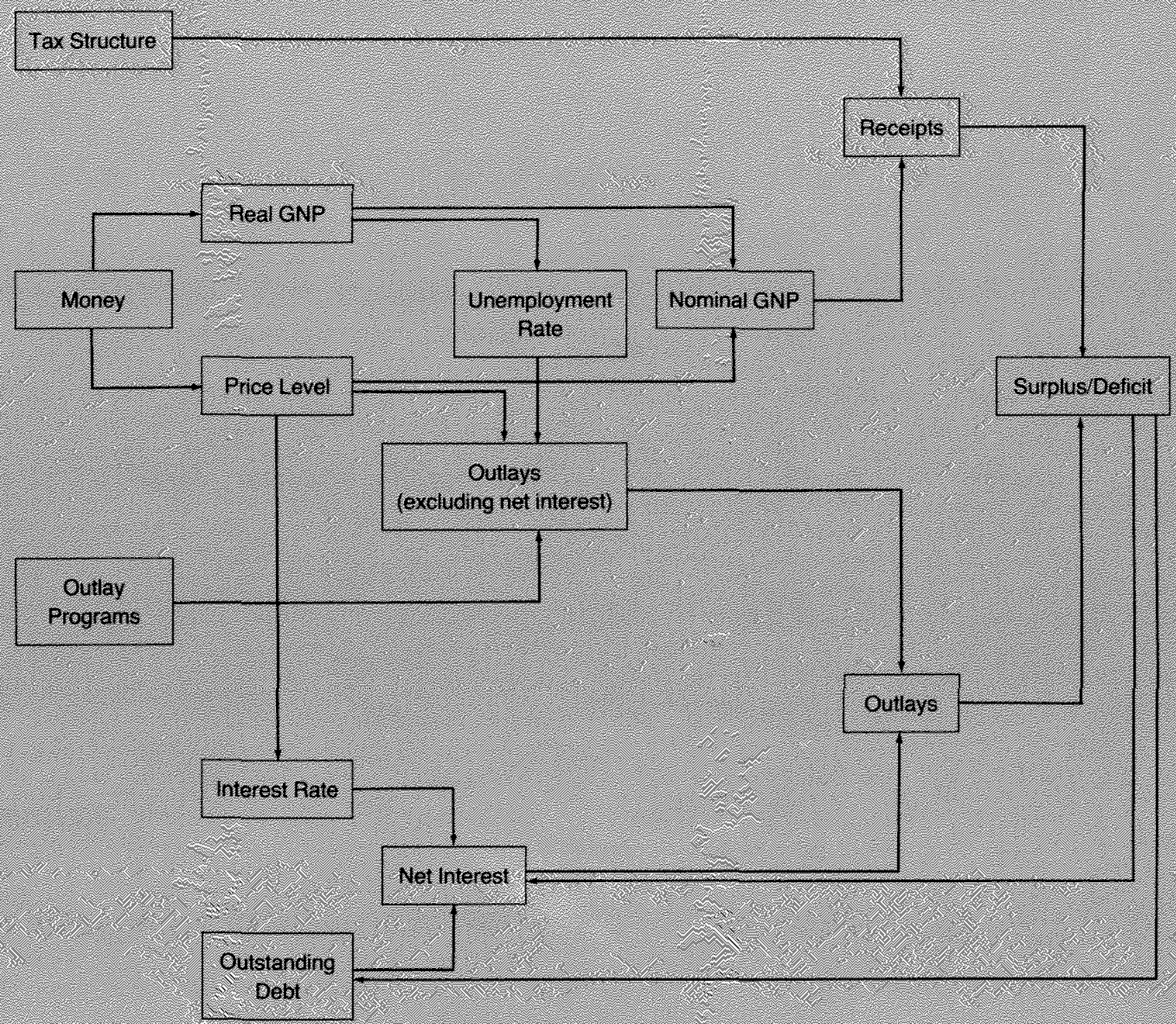

relative to GNP is a convenient way of summarizing budget policy under a set of economic assumptions over a period of years.

With the aid of this schematic diagram, the key variables can be identified easily. The model must be capable of tracing a path through time for real GNP, the price level (GNP deflator) and interest rates. Given the responses of receipts and outlays, a time path for the federal debt can be derived. Then, to explove whether the federal debt grows explosively over time, the size of the debt can be compared with GNP.

\section{Summary of the Model}

The model used in this article is an augmented monetary model.+ (For details, see appendix A.) The key feature of the model is that nominal GNP is deter-

\footnotetext{
"For further details on its properties, see Carlson and Hein (1983).
} 


\section{Chart 1}

\section{Federal Debt Held by the Public as a Percent of GNP}

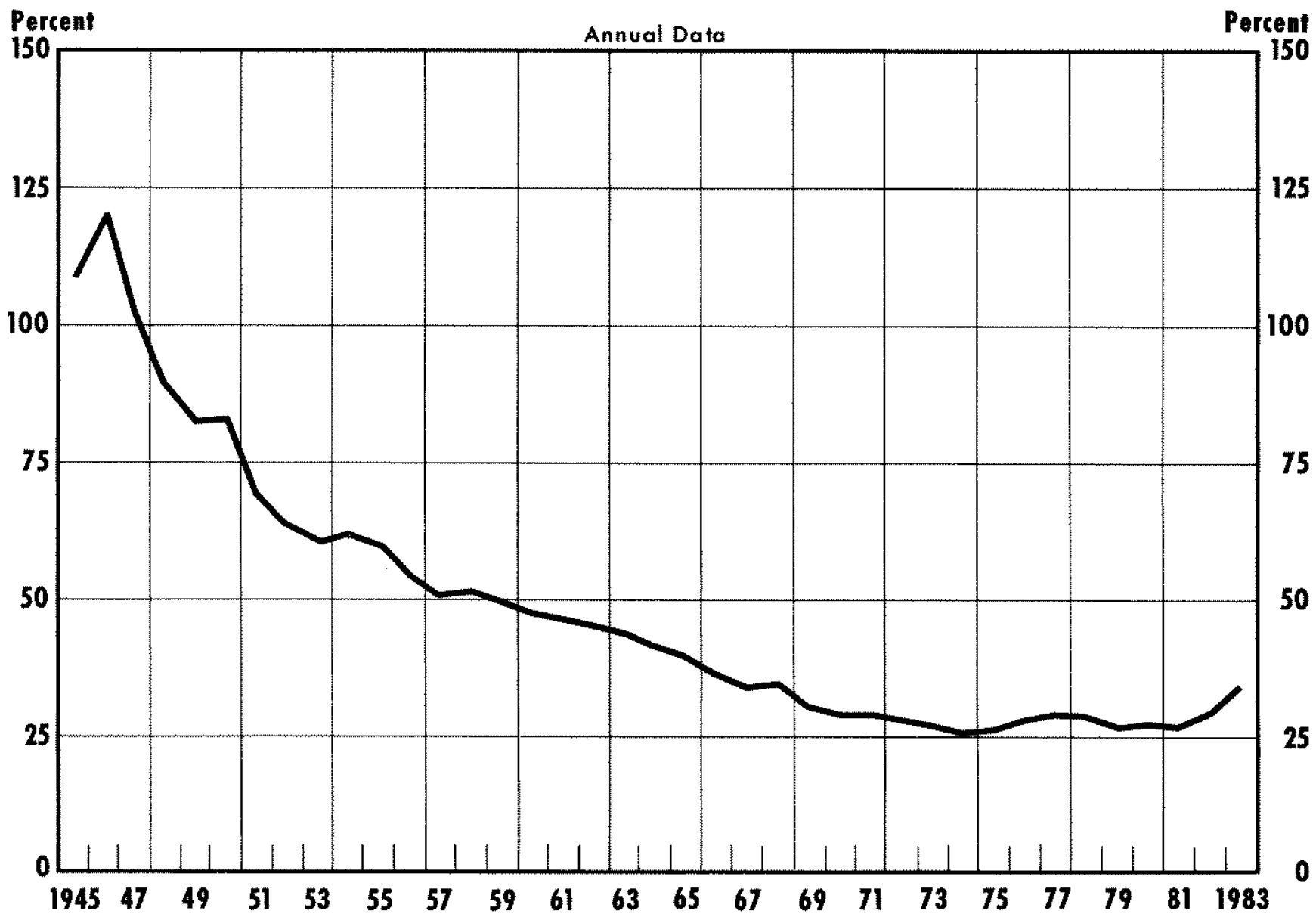

mined by current and lagged values of the money stock (M1): in other words, fiscal variables were not found to be significant in the determination of GNP." GNP is then divided between output and prices via a price equation. The GNP deflator is specified as a function of current and lagged values of the relative price of energy, demand pressure and anticipated price change. The 10-year Treasury bond rate is a function of past inflation. The 3 -month Treasury bill rate is a function of current and lagged values of changes in output and prices.

The budget portion of the model consists of an out lays equation and a receipts equation." These equa-

5This specification contrasts with that used in Carlson and Hein in that federal expenditures are omitted. For empirical support, see Hafer (1982).

6For further detail, see appendix B. See Carlson (1983) for further discussion of these equations. tions depend on a given outlay program and a set of tax laws, respectively, as well as the growth of real GNP and inflation. Interest payments are specified as a function of the two interest rates in the model, the portion of the budget deficit fnanced by the public, the size of the federal debt and the amount of debt maturing within a year. Several other budget identities are specified to genemate additional variables and to close the model so that it can be solved.

\section{Properties of the Model}

The properties of the model are monetarist. Changes in the growth rate of money change the growth of nominal GNP quickly, with the full effect achieved within five quarters. Initially, this change in nominal GNP is translated into a change in output (real GNP) because prices respond to changes in 
money growth with a much longer lag than nominal GNP does. The 3-month Treasury bill rate responds to a change in money via its effects on output and prices.' The Treasury bond rate, on the other hand, responds more slowly to money because it depends only on past prices.

Over the longer run, the effects of a change in monetary growth are reflected only in nominal variables, that is, nominal GNP, inflation and nominal interest rates. The achievement of full adjustment to a steadystate growth path takes about 30 years. For the fiveyear time horizon used by the government for budget analysis, output growth is still influenced by money growth; that is, the steady-state equilibrium has not yet been attained. To gain more insight into the future prospects for the budget, the model is simulated to its steady-state equilibrium, which occurs around 2015 . This longer-run perspective yields conclusions that differ from those that result from focusing on the conventional five-year budget horizon.

\section{THE BUDGET EFFECTS FOR ALTERNATIVE MONE'TARY POLICIES: 1984-89}

Each year the CBO provides a set of estimates that it calls "baseline projections." "These are projections of what federal receipts and outlays would be if current laws and programs were to continue for the next five years. In other words, despite the use of the term "projections," these are not forecasts of the budget; they are meant to be used as baseline estimates against which proposed changes in tax laws and spending programs can be measured and assessed.

In the process of preparing these estimates, the CBO develops a set of economic assumptions. ${ }^{n}$ This is a necessary part of the process because receipts and outlays depend crucially on economic conditions. Receipts depend, of course, on taxable income and sales which, in turn, depend on inflation and real growth. Similarly, outlays also are influenced by real growth, mainly via unemployment, and inflation, since a large number of programs are now indexed to the cost of living. Interest on the federal debt obviously depends

TNomally a third effect is included - a liquidity effect. However, using quarterly data the effect of contemporaneous changes in the growth rate of money was not found significant.

${ }^{8}$ For further discussion of the role of economic assumptions in the budgeting process, see Carlson. on the level of interest rates as well as the size of the deficit and the amount and maturity structure of outstanding debt.

The CBO's 1984 report on the budget is particularly bleak. ${ }^{9}$ According to the CBO's baseline estimates, the federal deficit will continue to grow in dollar terms throughout the 1984-89 period. Even when scaled against a growing GNP, the $\mathrm{CBO}$ concludes that the "deficit projections are obviously alarming." marized in the ratio of federal debt to GNP, the baseline projections indicate that the sharp increase in the ratio in 1982-83 will continue through the 1984-89 period.

\section{Economic Assumptions}

To assess the validity of the CBO's conclusions, the monetary model was simulated using three different monetary scenarios $-4,6$ and 8 percent growth of M1. These three alternative money growth assumptions produced alternative paths for real growth, inflation and interest rates.

Table 1 summarizes the CBO's baseline projections and the simulations by the monetary model. Although the CBO's projections are derived under the assumption that money growth will be 6 percent, their results are not generally consistent with those obtained from the monetary model using 6 percent growth in money. In particular, the $\mathrm{CBO}^{\prime}$ 's estimate of the dollar level of nominal GNP in 1989 falls about halfway between the results from simulations using 4 percent and 6 percent money growth.

The difference between the CBO's projections and the monetary model's simulations translates primarily into a difference in the projections for output. The CBO's projected level of real GNP for 1989 lies below that generated by the model using 4 percent money growth. Their relatively low projections of output tend

\footnotetext{
${ }^{\circ} \mathrm{CBO}$ (February 1984), part II. The analysis in this article (for both the CBO and the administration) is based on reports prepared in February 1984. Since then the CBO has prepared new baseline estimates (CBO, August 1984) and the administration has released its MidSession Review of the Fiscal Year 1985 Budget (OMB, August 15, 1984). The February estimates are used here because of their comparability; both the baseline estimates and the administration estimates are prepared on the basis of common CBO assumptions. Such comparability is not available for the August estimates. However, examination of the CBO's revised baseline estimates indicates that the conclusions are not materially affected. The estimates developed in this article are meant to serve as illustrations rather than precise projections.

taCBO (February 1984), part II, p. 6.
} 


\section{Table 1}

\section{Economic Variables; Model Simulations vs. CBO Baseline'}

\begin{tabular}{|c|c|c|c|c|c|c|}
\hline & 1984 & 1985 & 1986 & $19 a 7$ & 1988 & 1989 \\
\hline \multicolumn{7}{|c|}{ GNp (billons of dollars) } \\
\hline 1. $4 \%$ & $\$ 3763$ & 83969 & 8.454 & 18566 & 5.4093 & 85247 \\
\hline & $(5,9)$ & $(2.5 \times)$ & $(72)$ & $(7)$ & $(122$ & $(72)$ \\
\hline 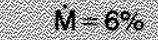 & 67\% & $(0458$ & 4,40 & 4052 & 5316 & 58619 \\
\hline & $(4,3)$ & n. 11 & $(9.5)$ & $(2.5)$ & $(95)$ & -2.5 \\
\hline $\mathrm{M}=\mathrm{g} \% \mathrm{~s}$ & 3.93 & $4+128$ & 4609 & 5156 & 5761 & 644 \\
\hline & $(1,4.6)$ & $(8,1)$ & $(1,8)$ & $(1.18)$ & $(11.8)$ & $(1,6)$ \\
\hline coso & 8651 & 3995 & 4390 & 4704 & 5084 & 5461 \\
\hline & $(10.3)$ & $(9.4)$ & $(6,6)$ & (6. 41 & (8. 11 & 178 \\
\hline \multicolumn{7}{|c|}{ Beal GIP (billons of 1972 dollars) } \\
\hline 11 & 17669 & $870 \%$ & 61762 & 51823 & 51802 & 81987 \\
\hline & $(6)$ & $(2,8)$ & $(32)$ & 1351 & $(6.2)$ & $(29)$ \\
\hline $1+6 \%$ & 1675 & 173 & 1817 & 1891 & 1952 & 1908 \\
\hline & $(92)$ & 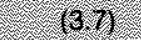 & $(46)$ & $(4)$ & $(3.2)$ & $(24)$ \\
\hline 11.64 & 682 & 1766 & 1874 & 1964. & 2031 & $20 \% 2$ \\
\hline & $(96)$ & (5.) & $(6,0)$ & $(4,6)$ & $(3.1)$ & $=-120$ \\
\hline 680 & $\left(\begin{array}{ll}1018 \\
(6.4)\end{array}\right.$ & $\begin{array}{l}1605 \\
(4)\end{array}$ & $174,(5)$ & 1805 & $\begin{array}{r}1866 \\
(3,4)\end{array}$ & $(1917)$ \\
\hline \multicolumn{7}{|c|}{ GhP Dellato $(1972=100)$} \\
\hline $11=4 \%$ & 2255 & 2326 & 2415 & 250.3 & 259.9 & 2708 \\
\hline & $(4,7)$ & $(0,3)$ & $(8,9)$ & $(3.6)$ & $(3,6)$ & $(4) 2$ \\
\hline$y=6 \%$ & 2255 & 2829 & 2468. & 2565 & 2722 & 2912 \\
\hline & $(47)$ & $(3.3)$ & $(47)$ & $(52)$ & $(61)$ & $(7.6)$ \\
\hline $10=0$ & 2256 & 2012 & 2459 & 2623 & 2837 & 3108 \\
\hline & $(47)$ & $(184)$ & $(6.4)$ & $(6.7)$ & $(62)$ & $(96)$ \\
\hline eBo & 205.0 & 26,6 & 248.9 & 2668 & 282. & 2840 \\
\hline & $(4)$ & $(5,1)$ & $(4.9)$ & $(4,7)$ & $(45)$ & $(4.3)$ \\
\hline \multicolumn{7}{|c|}{ Treasuy BII rate (percen) } \\
\hline N. 4.6 & $96 \%$ & 868 & $7.5 \%$ & $66 \%$ & $62 \%$ & 6. $1 \%$ \\
\hline $1=6 \%$ & 98 & 9.4 & 86 & 82 & 82 & 64 \\
\hline$n=8 \%$ & 9.9 & 100 & 98 & 96 & 10.1 & 106 \\
\hline cero & 89 & 80 & 84 & 8.2 & 60. & 8 \\
\hline \multicolumn{7}{|c|}{ Treasury pond hate (perceny) } \\
\hline $\mathrm{N}=\mathbf{4}^{\circ} \%$ & 12.48 & $11 \%$ & $97:$ & $89 \%$ & $6.6 \%$ & 818 \\
\hline$n=6 \%$ & 124 & 11. & $9 g$ & 95 & 6. 6 & 8.8 \\
\hline$k-0 \%$ & 124 & 112 & 10.2 & 101 & $10 \%$ & 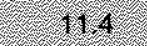 \\
\hline cro & 117 & 112 & 110 & 109 & $10 \%$ & 106 \\
\hline
\end{tabular}

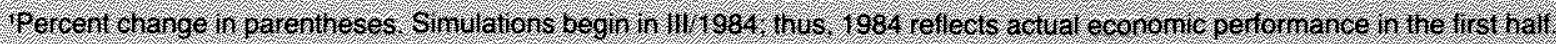

to increase their estimates of the baseline deficit; their estimates of outlays are higher and their estimates of receipts are lower. The CBO's projections of the price level, on the other hand, are quite close to the model's simulation using 6 percent money growth.

The differences in interest rate projections are com- pared at the bottom of table 1. The CBO's projections of the Treasury bill rate are consistent with the model's simulations using 6 percent money growth. The CBO's projections of the Treasury bond rate, on the other hand, are not; instead, they resemble more closely the model's result using 8 percent money growth. Even using that comparison, however, the 


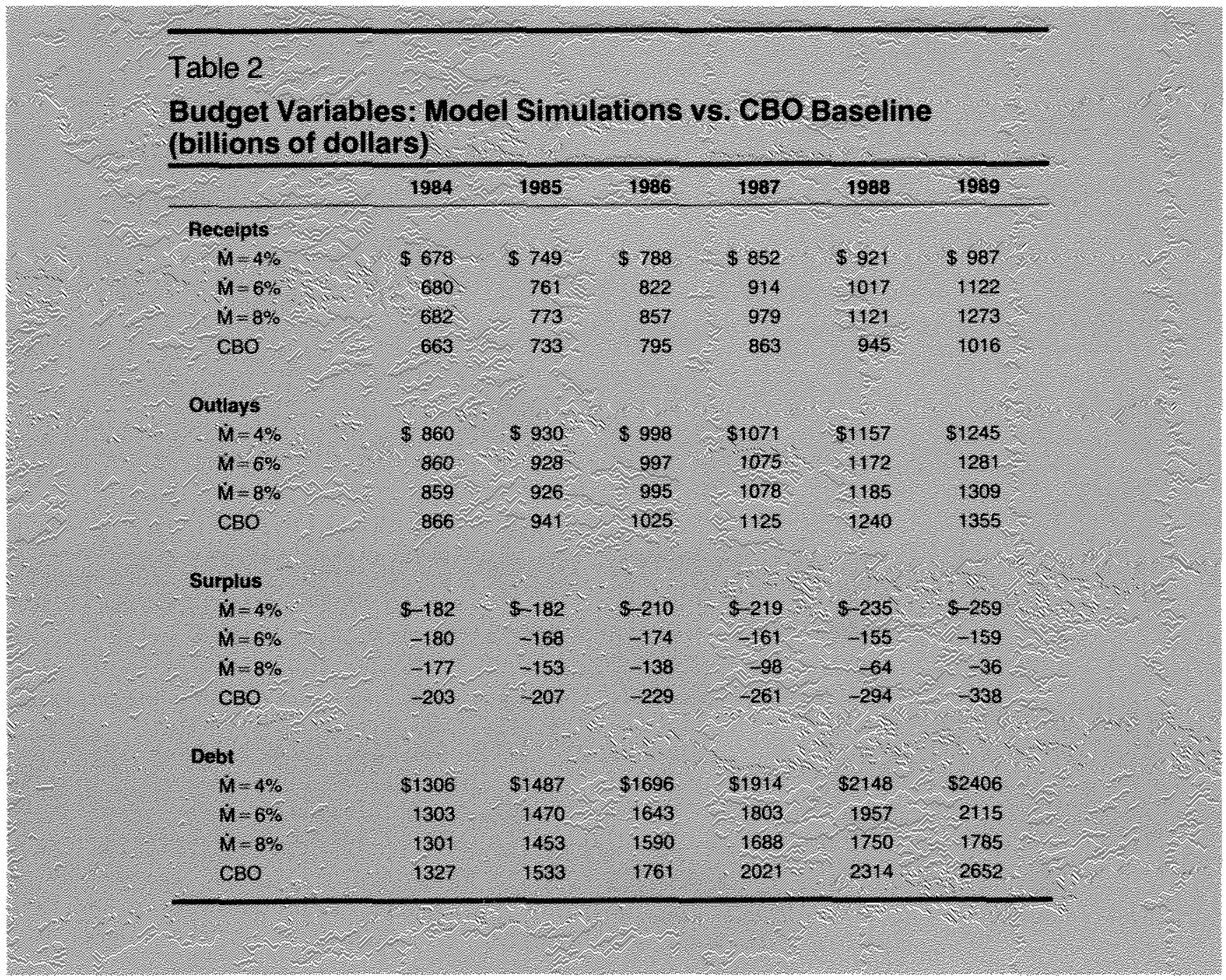

CBO's projections are generally higher throughout the period."

Higher interest rate estimates will produce higher estimates of the deficit. Furthermore, there is a crucial cumulative effect - highes interest rates add to the current deficit, which carries over to future years in the form of larger debt that must be financed.

\section{Simulating the Monetary Model with CBO's Baseline Estimates}

Table 2 summarizes the model's simulation of receipts and outlays and compares them with the CBO's

1The CBO projects a continuation of the large disparity between interest rates and inflation rates that has been observed recently. The monetary approach assumes implicity that interest rates even. tually will return to levels consistent with past relationships with inflation. estimates. The CBO's estimated receipts are slightly more than the model's estimates using 4 percent money growth. By 1989 , the CBO's estimate of receipts is $\$ 106$ billion below that generated by the model using 6 percent money growth. The composition of GNP is instrumental in producing this result. Because the $\mathrm{CBO}$ has a relatively low estimate of real growth, their estimate of the growth of receipts is also lower.

The CBO's estimated outlays are well above the highest estimate derived from the model. This difference again reflects the relatively low level of output that the CBO projects. As a result, outlays for unemployment compensation and the amount of deficit to be financed are higher as is the CBO's estimate for the interest rate on Treasury bonds. Differences in forecasts for interest rates can accumulate quickly into higher deficits via their effect on outlays. The model simulates interest payments using an equation esti- 
mated over a sample period of 1955-83 (see appendix B). The CBO does not estimate a single-interest payments equation; instead, its estimates are based on à detailed analysis of the components of the federal debt. ${ }^{\mathrm{2}}$

When the model's estimates of receipts and outlays are combined, the resulting budget picture is less bleak than the CBO's projections indicate. The model's surplus/deficit projections show clearly that the size of the projected deficit is very sensitive to the rate of monetary growth assumed. With 4 percent money growth, the deficit increases in dollar amounts through 1989; however, the rise is smaller than what the CBO projects. When 6 percent money growth is assumed, the budget deficit slowly declines. With even more rapid money growth, the budget moves toward surplus after 1989 , but, of course, inflation also is more apid.

Perhaps the most dramatic difference between the CBO's projections and those obtained from the model appears when the time paths for federal debt held by the public are compared. The cumulative effect of deficits over six years generates a public debt of $\$ 2,406$ billion with 4 percent money growth, $\$ 2,115$ billion with 6 peecent money growth, and $\$ 1,785$ billion with 8 percent money growth. Because the CBO projects higher deficits for every year than does the model, federal debt held by the public rises to $\$ 2,652$ billion in 1989 under the CBO projections.

\section{Simulating the Monetary Model with the Administration's Budget}

Given the model's simulations, either the budget situation or the outlook for inflation is bleak. Although the situation projected by the monetary model is not quite as bad as that seen by the CBO, the broad conclusions about continuing large budget deficits are generally the same. To determine what might be required to prevent continued large deficits, the administration's budget, as prepared in February 1984 and recalculated with the CBO's economic assumptions, is subjected to the same exercise used in the previous section."

\footnotetext{
'FFor further discussion of the CBO's procedures, see CBO (September 1984).

${ }^{1} \mathrm{OMB}$ (February 1984), and CBO (February 1984), An Analysis of the President's Budgetary Proposals for Fiscal Year 1985.
}

The administration's budget for $1985-89$, summarized in table 3 , can be compared with the CBO baseline estimates in table 2 . Note that the administration proposed modest increases in revenues, amounting to only an additional $\$ 23$ billion in 1989. According to the CBO's analysis of the administration's budget, the proposed revenue increases stem from the following:

(1) taxation of health insurance premiums;

(2) "structural reform" proposals, mainly in the form of limitations on tax-exempt leasing and on private-purpose tax-exempt bonds; and

(3) restrictions on tax shelters and on accounting and corporate tax abuses.

The proposals are not major; the CBO estimates that by 1987-89 primary revenues would be increasing only at a slightly faster rate than the CBO baseline estimates, 8.8 percent vs. 8.5 percent.

With regard to outlays, the administration program is somewhat more ambitious; outlays are projected to be $\$ 62$ billion less than the CBO's baseline estimate by 1989. The administration's program proposes considerable change in the composition of federal spending For 1989 , relative to the CBO's baseline projections defense spending would be $\$ 11$ billion higher, entitlement programs would be $\$ 15$ billion lower, nondefense discretionary spending would be $\$ 17$ billion lower, "offsetting receipts" would be higher by $\$ 6$ billion and net interest would be lower by $\$ 10$ billion Although these differences do not appear large, the administration's estimate for primary outlays for the 1987-89 period would be increasing at a 7.1 percen 1 rate, which compares with the CBO's baseline estimate of an 8.9 percent rate of increase.

The simulation results for the model using administration estimates are summarized in table 3 . When compared with table 2 , the contours of the deficit to GNP appear little different, especially in the early years. Closer inspection reveals that, for a given money growth, the administration program moves either to ward surplus or toward a smaller deficit by 1989 . This shows how relatively small changes in the growth rates of receipts and outlays can alter significantly the outlook for the deficit and the federal debt, even by 1989. It is to be noted, however, that the prospects for the debt improve in conjunction with an inflationary monetary policy. 


\section{Table 3}

\section{Budget Variables: Model Simulations vs. Administration Budget (billions of dollars)}

\begin{tabular}{|c|c|c|c|c|c|c|}
\hline & 1984 & 1985 & 1996 & 1967 & 1988 & 1069 \\
\hline \multicolumn{7}{|l|}{ recelpts } \\
\hline$M=4 \%$ & 6.6810 & $8+757$ & 6800 & 0.86 & 6.940 & 81009 \\
\hline$N=6 \%$ & 682 & 769 & 685 & 929 & 1037 & 1147 \\
\hline $14=0.6$ & 684 & 5.2701 & 870 & 995 & 1,48 & 301 \\
\hline $4 . \mathrm{mm}$ & 665 & $7,4)^{2}$ & 807 & 878 & 864 & 1089 \\
\hline \multicolumn{7}{|l|}{ Oullaos } \\
\hline 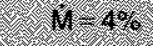 & 18.85 & 6.937 & 81002 & 81067 & 81132 & 81196 \\
\hline $1=6 \%$ & $\cos 7$ & 935 & 160 & (67) & 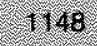 & 1227 \\
\hline U $0^{6} \%$ & 667 & 989 & 89.9 & 1078 & 1160 & 1254 \\
\hline Agmum & 866 & 947 & 1020 & 1419 & 1212 & 1296 \\
\hline \multicolumn{7}{|l|}{ Surplus } \\
\hline $11=1 \%$ & $17 \%$ & 5.181 & S. 202 & ? 200 & $8+12$ & S. 184 \\
\hline$M=6 \%$ & - 176 & $(x-166$ & -166 & 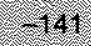 & - -1.10 & 80 \\
\hline 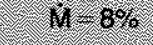 & -173 & -162 & $=129$ & $=78$ & -17 & 47 \\
\hline Almin & 201 & 206 & (- 228 & $-2,24$ & 248 & 254 \\
\hline \multicolumn{7}{|l|}{ Debt } \\
\hline $\mathrm{m}=4 \mathrm{co}$ & 61562 & 51482 & 81682 & 91882 & 6) & 82255 \\
\hline $10.6 \%$ & 1000 & 1865 & 1629 & 1769 & 1879 & 1958 \\
\hline M. 808 & $129 \%$ & $14+18$ & 7876 & 1653 & 1669 & 1622 \\
\hline aldillar & 1326 & 1529 & 1749 & 1990 & 2237 & 2490 \\
\hline
\end{tabular}

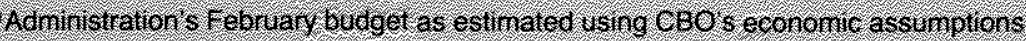

\section{THE BUDGET EFFECTS FOR}

\section{ALTERNATIVE MONETARY POLICIES: THE LONGER-TERM}

The previous comparisons demonstrate that the monetary model yields smaller deficit estimates than those using the $\mathrm{CBO}$ baseline projections. The chief conclusion from the simulations derived from the model is that faster money growth will produce smaller deficits up to $1989 .{ }^{\text {." }}$

Because public discussion of the effects of future deficits suggests that they are concerned with periods

${ }^{14}$ This result suggests that a goal of a balanced budget is meaningless unless there is an explicit accounting for monetary growth. No attempt is made here to assess the costs and benefits of aiming toward a balanced budget. What is clear is that the specification of such an objective requires a consideration of the possible accompanying inflation and variations in the rate of real growth. of time longer than five years, and because the model does not reach its full equilibrium in five years lime, it is informative to carry on with the simulation through time. To make a comparison possible between the CBO's analysis and the model's simulations for this longer period, both the CBO's baseline estimates for primary receipts and outlays and the administration's estimates were extended beyond 1989 at their average growth rates for the $1987-89$ period. This provided sufficient input for the model to continue the simulations past 1989. The model was simulated through 2015 , when it reaches steady-state equilibrium.

\section{Long-Term Simulations of CBO Baseline Estimates}

Chart 2 summarizes the simulation results using the model and the CBO baseline projections for the full period. Because dollar amounts are generally dif- 
Chart 2

\section{Federal Debt Held by the Public as a Percent of GNP Simulation Results Using CBO Baseline Estimates}

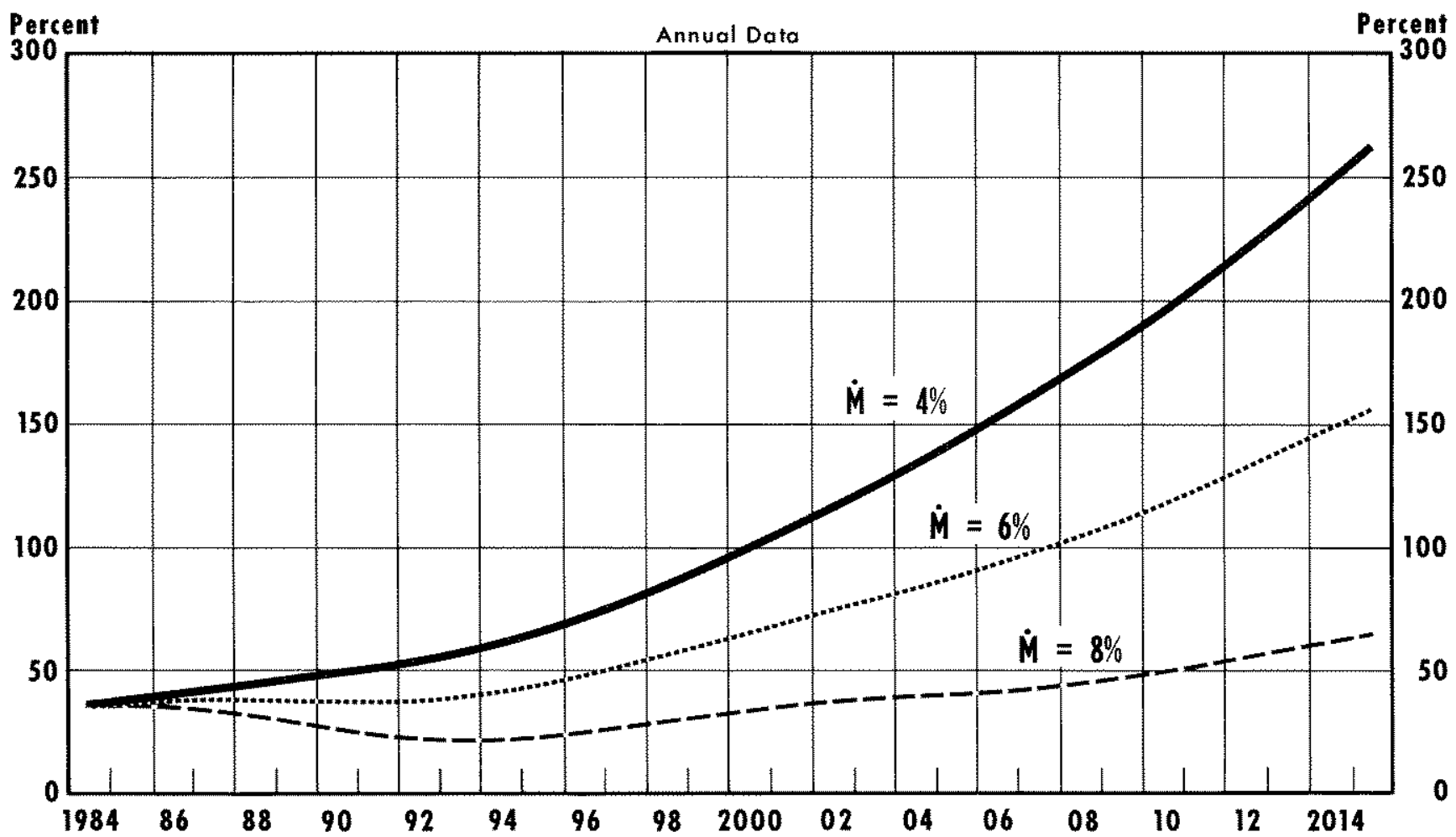

ficult to interpret meaningfully when considered over long time periods, the results for the federal debt are presented relative to GNP.

Chart 2 yields a surprising result. Here, federal debt held by the public, expressed relative to GNP, rises without limit for 4 and 6 percent money growth. Ony with 8 percent money growth does the debt appear to eventually decline relative to GNP.

Why the difference in the short-run and long-kun results? Isolating the reasons for this difference requires detailed examination of the time response of receipts and outlays to real growth, inflation and interest rates. The nature of the long-term results reflects primarily that outlays respond more slowly to inflation than receipts do. In addition, because it takes time for the debt to build up in response to deficits, the cumulative effect of deficits takes the form of increased outlays. These delays are further com- pounded because inflation responds more slowly to money growth than output does.

\section{Long-Term Simulations of the Administration's Budget}

Chat 3 summarizes the long-term simulations of the administration's budget. Here the differences from the 1984-89 horizon are also striking.

Using 4 percent money growth, the simulations show only a modest upward drift in the federal debt as a percent of GNP over the 30-year period. With 6 and 8 percent money growth, debt declines relative to GNP and is eventually eliminated, resulting in a net creditor position for the federal government. . $^{\text {. }}$

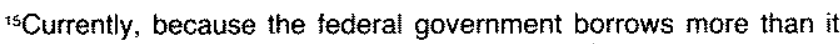
lends, it is a net debtor. Simulations showing the government as a net creditor are only meant to be illustrative. They shoud not be consirued as forecasts 


\section{Chart 3 \\ Federal Debt Held by the Public as a Percent of GNP Simulation Results Using Administration Budget}

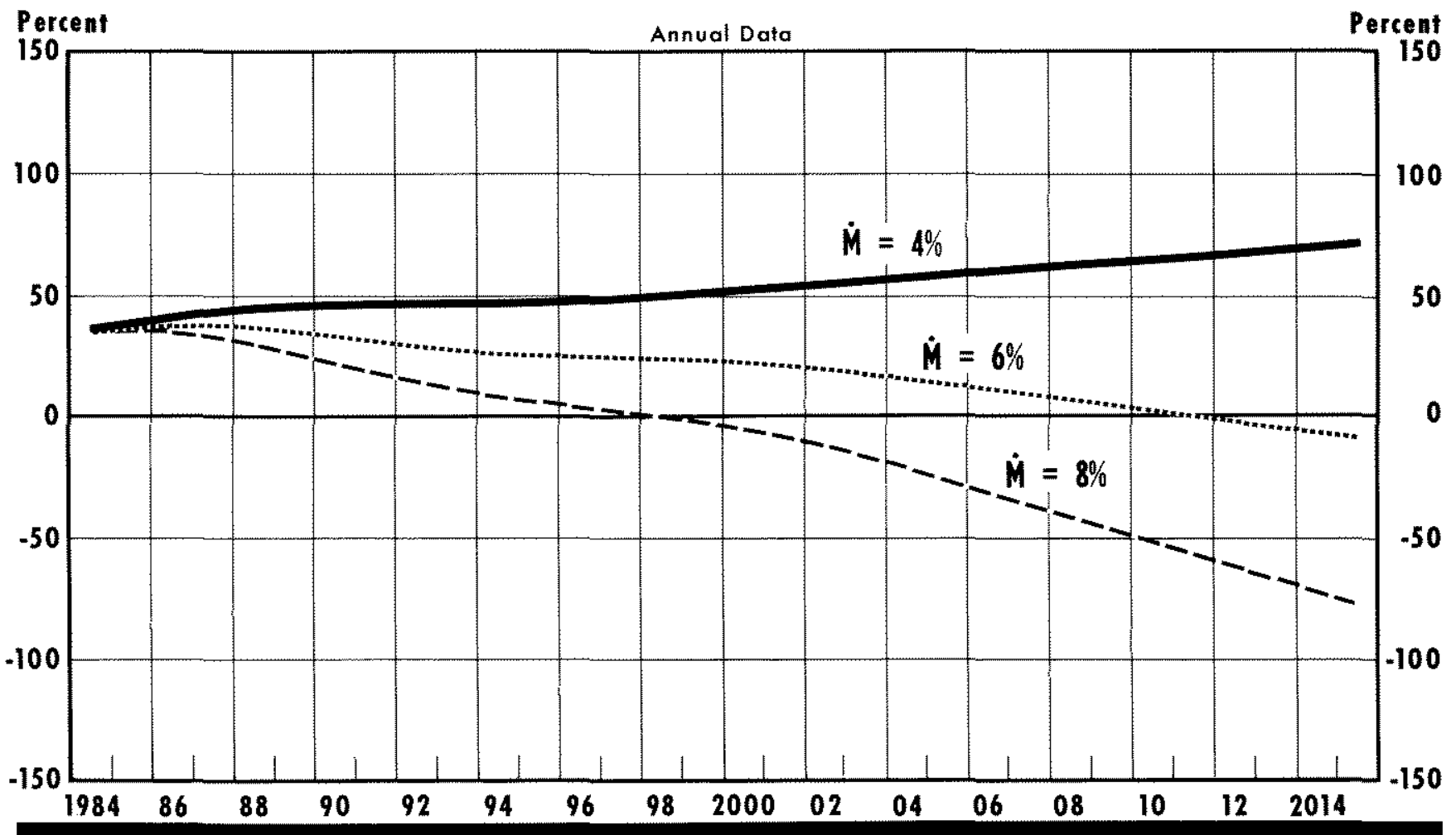

\section{SUMMARY}

There is a developing consensus that budget deficits are growing at disquieting rates. To examine the likelihood of future deficits, a monetary model was expanded to include the determination of budget variables. Key budget variables were recalculated using the CBO's baseline estimates and the administration's February 1984 budget. These simulation results indicate that the prospects for a balanced budget depend on the time path of monetary growth. In particular, achieving a balanced budget is facilitated by faster money growth.

Another conclusion that derives from this study is that a five-year planning horizon seems too short to judge whether a particular set of policies is really reducing the sequence of future deficits. Because of the lag structure between policy variables and economic variables, a decade or more might be necessary before the full impact on deficits can be discerned.

The charts and tables in this article should not suggest that considerable precision is possible in the preparation of budget estimates - especially those for a far distant period. The simulations are meant to be illustrative; they are conditioned by a large number of assumptions, not the least of which is the model chosen to derive the simulations. Nevertheless, the major conclusion stands: the long-term process of reducing budget deficits is difficult, but possible. In particular, receipts and outlays depend on key economic varia bles like real growth, inflation and interest rates; these, in turn, depend crucially on the rate of monetary expansion. Thus, fiscal plans to reduce deficits over time must be coordinated with monetary policy actions if they are to be successful; any choice of deficit reduction via faster money growth must be assessed in conjunction with the possible inflationary costs involved.

\section{REFERENCES}

Carison, Keith M. "The Critical Role of Economic Assumptions in the Evaluation of Federal Budget Programs, "this Review (October $1983)$, pp. $5-14$. 
Carlson, Keith M., and Scott E. Hein. "Four Econometric Models and Monetary Policy: The Longer-Run View," this Feview (January 1983), pp. 13-23

Congressional Budget Office. The Economic Ouflook, A Report to the Senate and House Committees' on the Budget - Part I (U.S. Government Printing Office, February 1984).

Congressional Budge: Office. Baseline Budget Projections for Fiscal Years 1985-1989, A Report to the Senate and House Committees on the Budget - Part Il (GPO, February 1984).

Congressional Budget Otfice. An Analysis of the President's Budgetary Proposals for Fiscal Year 1985, prepared at the request of the Senate Committee on Appropriations (GPO, February 1984).
Congressional Budget Office. The Economic and Budget Outiook An Update, A Report to the Senate and House Committees on the Budget (GPO, August 1984).

Congressional Budget Office. Federal Debt and interest Costs, Special Study (GPO, September 1984).

Hafer, R. W. "The Role of Fiscal Policy in the St. Louis Equation," this Review (January 1982), pp. 17-22.

Klein, L. R. "The Importance of the Forecast," Journal of Forecasting (January-March 1984), pp. $1-9$.

Office of Management and Budget. Budget of the United States Government: Fiscal Year 1985 (GPO, February 1984).

Office of Management and Budget. Mid-Session Review of the 1985 Budget (GPO, August 15, 1984).

\section{Appendix A A Monetary Model}

The model used for simulations of the economic variables is summarized below. A dot over a variable indicates compounded annual rate of change. Most

(1) GNP equation

Sample period: $1 / 1960-\mathrm{W} / 1981$

$$
\begin{aligned}
& \dot{Y}_{1}=2.67+1.14 \stackrel{4}{\Sigma} \dot{M}_{t-i} \\
& \text { (2.60) } \quad(6.30) \mathrm{i}=0 \\
& \mathrm{R}^{2}=.36 \quad \mathrm{SF}=3.65 \quad \mathrm{DW}=2.11
\end{aligned}
$$

(2) Price equation

Sample period: V/1960-IV/1983

$$
\begin{aligned}
& \dot{\mathrm{p}}_{\mathrm{i}}=\underset{(2.30)}{.87}+.14 \underset{\mathrm{i}=1}{\sum} \dot{\mathrm{P}} \mathrm{K}_{\mathrm{t} w \mathrm{i}}+\underset{(5.80)}{.09} \sum_{\mathrm{i}=0}^{5}\left(\dot{\mathrm{X}}_{1-\mathrm{i}}-\dot{\mathrm{X}} \mathrm{F}_{\mathrm{k}-\mathrm{i}}^{*}\right) \\
& +1.11 \dot{\mathrm{PA}} \\
& \text { (12.35) } \\
& \overline{\mathbf{R}}^{z}=.72 \quad \mathrm{SE}=1.41 \quad \mathrm{DW}=2.01 \quad \hat{\rho}=.15
\end{aligned}
$$

(3) Treasury bill rate equation

Sample period: $/ / 1960-\mathrm{V} / 1983$

$$
\begin{aligned}
& \mathrm{RS}_{\mathrm{t}}=.55 \stackrel{10}{\sum} \dot{\mathrm{X}}_{\mathrm{i}-\mathrm{i}}+.99 \stackrel{10}{\sum} \dot{\mathrm{P}}_{\mathrm{i}-\mathrm{i}} \\
& (3.28) \mathrm{i}=0 \quad(6.45) \mathrm{i}=0 \\
& \widetilde{\mathrm{R}}^{2}=.15 \quad \mathrm{SE}=.90 \quad \mathrm{DW}=1.90 \quad \hat{\mathrm{\rho}}=.91
\end{aligned}
$$

equations are estimated with Almon constraints on the coefficients. Absolute values of t-statistics are in parentheses.

(4) Treasury bond rate equation

Sample period: $/ / 1960-[V / 1983$

$$
\begin{aligned}
& \mathrm{RL}_{L_{1}}=2.88+\underset{(1.96)}{.96} \sum_{(3.75)}^{20} \dot{\mathrm{p}}_{1,1} \\
& \overline{\mathrm{R}}^{z}=.13 \quad \mathrm{SE}=.51 \quad \text { DW }=1.77 \quad \hat{\rho}=.95
\end{aligned}
$$

(5) GNP identity

$$
Y_{t}=\left\{P_{r} / 100\right\} X_{i}
$$

(6) Demand pressure definition

$$
\left.\dot{\mathrm{X}} \mathrm{F}_{\mathrm{t}}^{*}=\left(\mathrm{XF} / \mathrm{X}_{1-1}\right)^{+}-1\right) \cdot 100
$$

(7) Price anticipations definition

$$
\dot{\mathrm{PA}}_{1}=.96 \sum_{\mathrm{i}=1}^{21} \dot{\mathrm{P}}_{\mathrm{ti}}
$$

\footnotetext{
$Y=$ nominal GNP

$M=$ money stock (M1)

$p^{3}=$ GNP deflator $(1972=100)$

PE = relative price of energy

$X=$ output in 1972 dollars

$\mathrm{XF}=$ potential output /Rasche-Tatom/

$R L=$ Treasuly bond rate

RS = Treasury bill tate
} 


\section{Appendix $B$ Budget Model}

To estimate the effect on budget projections of an alternative set of economic assumptions, the following budget variables were estimated:

1) primary receipts: total receipts minus earnings of the Federal Reserve System

2. primary outlays: total outlays minus net interest

3) net interest

The basic source for estimates of the relevant elasticities were estimates published by the CBO (February 1984), Part I. Net interest was estimated using fiscal year data for 1955-83.

\section{Primary receipts}

The implied coefficients for receipts as derived from estimates prepared by the CBO were:

$$
\begin{aligned}
\Delta \dot{\mathrm{R}}_{1}^{\mathrm{P}}= & .75 \Delta \dot{\mathrm{X}}_{1}+.81 \Delta \dot{\mathrm{X}}_{1-1}-.01 \Delta \dot{\mathrm{X}}_{1-3}+.26 \Delta \dot{\mathrm{X}}_{\mathrm{t-3}} \\
& +.14 \dot{\mathrm{X}}_{1-1}+.21 \dot{\mathrm{X}}_{1-\mathrm{s}}+.75 \Delta \dot{\mathrm{P}}_{\mathrm{t}}+.36 \Delta \dot{\mathrm{P}}_{t-1} \\
& +.02 \Delta \dot{\mathrm{P}}_{1-2}+.16 \Delta \dot{\mathrm{P}}_{1-3}-.06 \Delta \dot{\mathrm{P}}_{1-4}+.13 \Delta \dot{\mathrm{P}}_{t-3}
\end{aligned}
$$

where

$$
\begin{aligned}
\Delta \dot{\mathrm{R}}_{\mathrm{r}}^{\mathrm{P}}= & \text { deviation of percent change in primary } \\
& \text { receipts from baseline estimate in fiscal } \\
& \text { year } \mathrm{t} \\
\Delta \dot{\mathrm{X}}_{1}= & \text { deviation of percent change in real GNP } \\
& \text { from baseline estimate in year } \mathrm{t} \\
\Delta \dot{\mathrm{P}}_{1}= & \text { deviation of percent change in GNP defla- } \\
& \text { tor from baseline estimate in year } t
\end{aligned}
$$

\section{Primary outlays}

The implied coefficients for outlays as derived from estimates prepared by the CBO were:

$$
\begin{aligned}
\Delta \dot{\mathrm{O}}_{\mathrm{t}}^{r}= & .25 \Delta \dot{\mathrm{X}}_{\mathrm{t}}+.06 \Delta \dot{\mathrm{X}}_{1-3}+.03 \Delta \dot{\mathrm{X}}_{1-3}-.03 \Delta \dot{\mathrm{X}}_{1-3} \\
& +.01 \Delta \dot{\mathrm{X}}_{1-3}-.02 \Delta \dot{\mathrm{X}}_{1-5}+.00 \Delta \dot{\mathrm{P}}_{1}+.39 \Delta \dot{\mathrm{P}}_{1-1} \\
& +.21 \Delta \dot{\mathrm{P}}_{1-3}+.14 \Delta \dot{\mathrm{P}}_{1-3}+.00 \Delta \dot{\mathrm{P}}_{1-4}+.15 \Delta \dot{\mathrm{P}}_{1-3}
\end{aligned}
$$

where

$\Delta \dot{O}_{t}^{\prime}=$ deviation of percent change in primary outlays from baseline estimate in fiscal year $t$

\section{Net interest}

The estimation form of the net interest equa tion was derived from the following equation:

$$
I_{1}=i_{8}\left[-\left(S_{1}^{\prime}+S_{1}^{\prime \prime}\right)\right]+\left(i_{1}-\frac{I_{t-1}}{D_{1-1}}\right\} \frac{D_{1-1}}{M_{k-1}}+I_{1-3}
$$

$$
\begin{aligned}
& \text { where } \\
& I_{\mathrm{t}} \quad \text { - net interest in fiscal year } t \\
& i_{1} \quad=\text { average yield on 3-month Treasury bills } \\
& S_{1}^{\top}=\text { budget surplus in fiscal year } t=S_{7}^{\mu}-I_{1}+ \\
& \pi_{i}^{r n} \\
& S_{t}^{\prime} \quad \text { - primary surplus in fiscal year } t \\
& \pi_{1}^{\mathrm{rR}}=\text { earnings of the Federal Reserve System in } \\
& \text { fiscal year } t \\
& S_{1} \quad=\text { financing from other than borrowing } \\
& \text { from the public in fiscal year } t \\
& D_{1} \text { - federal debt held by the public in fiscal } \\
& \text { year } t \\
& \mathrm{M}_{1} \quad \text { = average length to maturity of federal debt } \\
& \text { (in years) at end of fiscal year t }
\end{aligned}
$$

The first term on the right-hand side represents borrowing from the public in the current fiscal year. The second tem is an approximation of the change in interest cost due to refinancing maturing debt. This equation was solved for $I$, in the form shown below. Since it is an approximation, the equation was estimated using data from 1953-83:

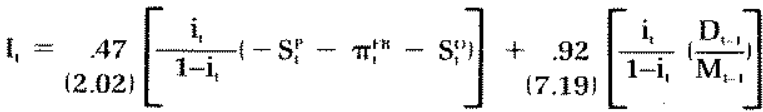

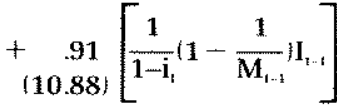

$$
\begin{aligned}
& \overline{\mathrm{R}}^{2}=.99 \quad \mathrm{SE}=2.05 \quad \mathrm{DW}=1.95 \quad \rho_{3}=-.34 \quad \rho_{2}=.17
\end{aligned}
$$

